\title{
THE IMPORTANCE OF ORAL HEALTH BEHAVIOUR OF CHILDREN FOR THEIR ORAL HEALTH
}

\author{
Andjelic Ivana, ${ }^{1}$ Matijevic Snezana, ${ }^{2}$ Andjelic Jasminka ${ }^{1}$ \\ ${ }^{1}$ University of Montenegro, Faculty of Medicine Podgorica, Montenegro \\ ${ }^{2}$ Primary Heath Care Center Tivat, Montenegro
}

Primljen/Received 24. 05. 2015. god.

Abstract: Introduction. Caries or tooth decay regardless of the good knowledge of the nature of the disease and the possibility of its effective prevention is still the most widespread disease in our population. It also very often threatens the functions of organs and even the entire organism. Health culture is an integral part of general culture and health education plays an important role in maintaining health of individuals. Aim. The main objective of this study is to determine the influence of oral health behaviour of schoolchildren aged 12 to 14 on their oral health. The schoolchildren attended the seventh and eight grade at Drago Milovic Elementary School in Tivat. Method. The survey was conducted during the period from the end of January to April 2015 at Drago Milovic Elementary School in Tivat. It comprised all seventh and eight-graders that were at school those days. The survey instrument was a questionnaire specially designed for this study and it consisted of 36 closed-ended questions. Clinical examination of oral health in children was used as an additional research instrument. Assessment of oral health was carried out under natural light with dental mirror and probe according to WHO recommendations. The parameter used to assess the state of oral health was DMFT index - the number of carious, extracted and filled teeth. In addition, the assessment of oral hygiene was conducted using soft debris index according to Green-Vermillion which determines absence or presence, quantity and distribution of dental plaque and other soft deposits. Results. The majority of students stated that they lack knowledge regarding the effectiveness of fluoride toothpaste (69.4\%). It was found that the lowest incidence of caries occurred among those students who think that teeth should be brushed after every meal, and the highest incidence of this diagnosis occurred in respondents who think that teeth should be brushed once a day. Half of the surveyed
Prihvaćen/Accepted 24. 06. 2015. god.

students believe that teeth should be brushed most often after every meal and more than half of excellent students (55.6\%) believe so. DMFT index for study population was 1.87 while Green-Vermillion soft debris score of oral hygiene was 2 in largest number of students (49.5\%). Conclusion. Looking at the results it can be concluded that dental care in this area does not significantly affect the improvement of oral health in children. Therefore a greater attention should be paid to continuous education programmes and gaining knowledge about oral health and hygiene of the mouth and teeth.

Key words: students, oral health, health education, DMFT index, Green-Vermillion index.

\section{INTRODUCTION}

Caries or tooth decay regardless of the good knowledge of the nature of the disease and the possibility of its effective prevention is still the most widespread disease in our population. It also very often threatens the functions of organs and even the entire organism. Even in ancient times it was known that dental foci may be the cause of subsequent diseases and thus for the treatment of arthritis the tooth extraction was advised (1). Different diseases such as infective endocarditis, an infection of head and neck, respiratory infections, diseases of gastrointestinal tract, skin diseases, bone disease, premature birth, can be caused by microorganisms from odontogenic foci (2). Health culture is an integral part of general culture and health education plays an important role in maintaining health of individuals. Special attention should be paid to education of parents and children and implementation of prevention programmes in order to ensure not only adequate oral health of children, but also a better quality of life (3). 


\section{ORAL HEATH BEHAVIOUR AS DETERMINANT OF ORAL HEALTH}

Parents have very important role in maintaining oral health in children because children attitude formation is based on the opinions and actions of their parents in preschool age. Studies have shown that the control of oral hygiene in children by their parents as well as good oral hygiene habits of parents have a statistically significant impact on the dental health of a child (4). However, even today it is not rare that among very young children tooth decay occurs due to unhealthy diet and lack of oral hygiene (5). Children should be educated on the consequences of their risky behavior in order to accept responsibility for their own health. Numerous studies conducted so far confirmed the possibility of high preventability of oral diseases and therefore it is very important to start with prevention and education programmes at preschool age so that children can get information about caries and periodontal diseases as well as proper tooth brushing techniques and use of assistive devices for oral hygiene (6). The main goal of the implementation of health education programmes is to reduce the incidence primarily of dental caries and periodontal diseases but also of other diseases of the oral cavity (7).

Apart from education, regular preventive dental check-ups can also prevent oral diseases. Unfortunately, this fact is not fully appreciated by the parents of a large number of school-age children (8). The study conducted in Norway found that family characteristics such as marital status and education level of parents, ethnicity, parents lifestyle as well as the mother's diet during pregnancy are associated with the development of caries in preschool children (9). Correlation between dental health and socio-economic status is higher at that age than in older children. A higher prevalence of dental caries has been demonstrated in children in families with low income, lower education level of mothers and those from large families (10). Also, one of the studies has shown that parents with proper oral hygiene habits paid more attention to their children's tooth brushing, prevention of caries as well as diet rich in sugar compared to parents with bad oral hygiene (11). A study conducted in Iran showed a statistically significant difference between plaque index of children and education level of their mothers as well as between the toothbrushing frequency in parents and their children (12).

\section{RESEARCH GOAL}

The main objective of this study is to determine the influence of oral health behaviour of school chil- dren aged 12 to 14 on their oral health. The schoolchildren attended the seventh and eighth grade at Drago Milovic Primary School in Tivat, Montenegro. The specific objective is to identify habits, attitudes, and behaviour of school children as well as the state of their oral health that determines the occurrence of oral diseases.

\section{METHOD}

The survey was conducted during the period from the end of January to April 2015 at Drago Milovic Elementary School in Tivat. The survey comprised all seventh and eighth-graders that were at school those day. All children have voluntarily agreed to participate in the study.

Coverage rate was about $95 \%$, since total number of students in above mentioned grades in this school is 432 which means that 20 students were absent on days the survey was conducted.

The survey instrument was a questionnaire specially designed for this study and it consisted of 36 closed-ended questions. It had three parts which related to children's knowledge about oral health, behaviour of children in relation to oral health and their attitudes towards oral health. Clinical examination of oral health in children was used as an additional research instrument. Assessment of oral health was carried out under natural light with dental mirror and probe according to WHO recommendations. The parameter used to assess the state of oral health was DMFT index - the number of carious, extracted and filled teeth. In addition, assessment of oral hygiene was conducted using soft debris index according to Green-Vermillion which determines absence or presence, quantity and distribution of dental plaque and other soft deposits. Lesions with clearly formed cavity on the surface of the tooth were marked as dental caries. Changes in transparency and initial enamel demineralization with intact surfaces which did not lead to discontinuation of dental tissue were not registered. Clinical examination at school was done by the dentist trained to use abovementioned indices. During the examination children were advised how to maintain proper oral hygiene and that was demonstrated on a model as well. They were also given advice on proper nutrition and fluoride prophylaxis.

The survey data were presented using descriptive statistics.

\section{RESULTS}

The study included a total of 412 seventh and eighth-graders. 

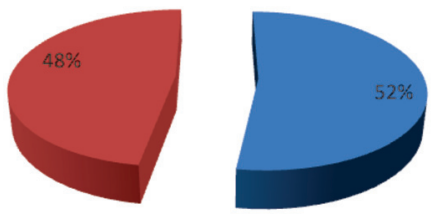

mBOYS MGIRLS

Figure 1. Distribution of respondents by gender

Of all respondents $52.3 \%$ were boys (Figure 1).

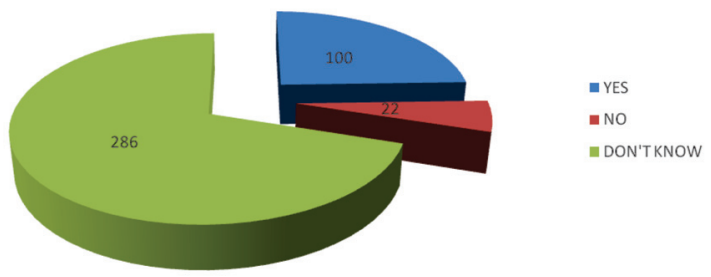

Figure 2. Knowledge about effectiveness of fluoride toothpaste

The majority of pupils stated that they lack knowledge regarding the effectiveness of fluoride toothpaste $(69.4 \%)$ while $5.4 \%$ of them believe that fluoride toothpaste does not affect dental health. Almost one in four respondents $(24.5 \%)$ said that fluoride toothpaste is effective in maintaining oral health (Figure 2).

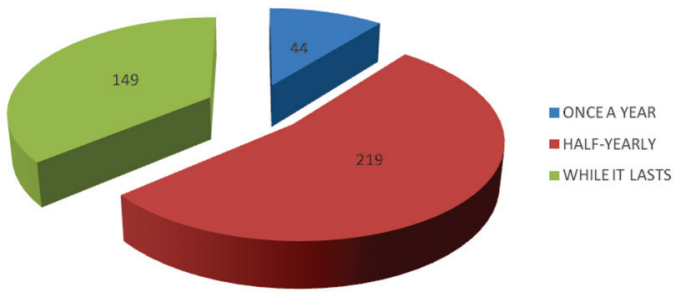

Figure 3. Frequency of changing toothbrushes

Slightly more than half of the respondents $(53.2 \%)$ change their toothbrush every six months, $10.7 \%$ of them do so only once a year while more than a third of respondents use a toothbrush while it lasts (Figure 3).

One-way analysis of variance (ANOVA) was used to study the effects of attitudes of how often one should brush the teeth on the values of diagnostic data regarding occurrence of caries. Respondents were divided into five groups based on their attitude to the frequency of tooth brushing: at least once a day, twice a day, and not every day, after every meal and not knowing how often teeth should be brushed. It was found that the lowest incidence of caries occurred in group four i.e. those who believe that teeth should be brushed after every meal. The highest incidence of caries occurred in gro-

Table 1. The impact of students' attitude about toothbrushing frequency on occurrence of caries

\begin{tabular}{|l|c|c|c|}
\hline ATTITUD TOWARDS TOOTH BRUSHING & MD & SE & Sig. \\
\hline At least once a day & 1,27 & 0,33 & 0,002 \\
\hline At least twice a day & 1,31 & 0,39 & 0,001 \\
\hline It is not necessary to brush your teeth every day & $-1,27$ & $-2,21$ & 0,002 \\
\hline After each meal & $-1,36$ & $-0,39$ & 0,001 \\
\hline I do not know & $-1,44$ & $-4,80$ & 0,219 \\
\hline ANOVA: $\mathrm{F}=6,530 ; \mathrm{p}<0,001$ & & & \\
\hline
\end{tabular}

Table 2. Corelation between toothbrushing frequency and educational achievement at the end of the previous school year

\begin{tabular}{|l|c|c|c|c|c|c|}
\hline \multirow{2}{*}{$\begin{array}{c}\text { ACHIEVEMENT } \\
\text { AT THE END } \\
\begin{array}{c}\text { OF THE } \\
\text { PREVIOUS } \\
\text { SCHOOL YEAR }\end{array}\end{array}$} & $\begin{array}{c}\text { At least } \\
\text { once a day }\end{array}$ & $\begin{array}{c}\text { At least } \\
\text { twice a day }\end{array}$ & $\begin{array}{c}\text { It is not } \\
\text { necessary to } \\
\text { brush your } \\
\text { teeth every } \\
\text { day }\end{array}$ & $\begin{array}{c}\text { After each } \\
\text { meal }\end{array}$ & $\begin{array}{c}\text { I don't } \\
\text { know }\end{array}$ & Total \\
\hline Unsatisfactory & 0 & 3 & 1 & 2 & 0 & 6 \\
\hline Took makeup exam & 2 & 3 & 0 & 1 & 2 & 8 \\
\hline Satisfactory & 2 & 4 & 0 & 1 & 1 & 8 \\
\hline Good & 8 & 28 & 0 & 29 & 3 & 68 \\
\hline Very good & 11 & 51 & 2 & 69 & 2 & 135 \\
\hline Excellent & 13 & 69 & 0 & 104 & 1 & 187 \\
\hline Total & 36 & 158 & 3 & 206 & 9 & 412 \\
\hline X squared test $=65,579 ; \mathrm{p}<0,001$ & \multicolumn{7}{|l|}{} \\
\hline
\end{tabular}


Table 3. Changes in teeth diagnosed in respondents

\begin{tabular}{|l|c|c|c|}
\hline \multirow{2}{*}{ Number of Teeth } & \multicolumn{3}{|c|}{ Type of change } \\
\cline { 2 - 4 } & CARIES & EXTRACTION & FILLING \\
\hline No changes in teeth & 80 & 296 & 91 \\
\hline Changes in one tooth & 61 & 52 & 41 \\
\hline Changes in two teeth & 96 & 41 & 63 \\
\hline Changes in three teeth & 81 & 17 & 78 \\
\hline Changes in four teeth & 47 & 6 & 34 \\
\hline Changes in five teeth & 23 & 0 & 19 \\
\hline Changes in six teeth & 10 & 0 & 3 \\
\hline Changes in seven teeth & 9 & 0 & 5 \\
\hline Changes in eight teeth & 3 & 0 & 2 \\
\hline Changes in nine teeth & 0 & 0 & 0 \\
\hline Changes in ten teeth & 1 & 0 & 0 \\
\hline Changes in eleven teeth & 0 & 0 & 412 \\
\hline Changes in twelve teeth & 1 & 412 & \\
\hline TOTAL & 412 & & \\
\hline DMF INDEX = 1,87 & \multicolumn{3}{|c|}{} \\
\hline
\end{tabular}

up one i.e. those who think the teeth should be brushed once a day (Table 1).

Data analysis showed that there was a statistically significant difference between attitudes of children towards frequency of tooth brushing and their educational achievement. Half of the surveyed children think that teeth should be brushed after every meal and among excellent students more than half of them $(55.6 \%)$ think so, slightly less very good ones $(51 \%)$, followed by those who are good (42.6\%) while it is less present in children with bad grades (Table 2).

DMFT index for study population was 1.87 and the most common identified change was caries $(81.65 \%)$, most frequently occurred in two teeth, then three, followed by one while there were students with eight or ten carious teeth (Table 3 ). Filled teeth were also frequently present $(77.9 \%)$ while number of students with extracted teeth was the lowest (28.2\%) (Table 3).

It was found that only one student had no deposits (Figure 4) using Green-Vermillion soft debris index. The largest number of students had debris score 2

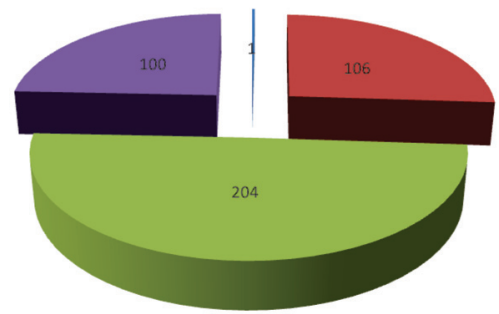

- NO DEBRIS

- DEBRIS SCORE 1

IDEBRIS SCORE 2

- DEBRIS SCORE 3

Figure 4. Green-Vermillion index soft plaque index (oral hygiene index)
$(49.5 \%)$, followed by score $1(25.7 \%)$ and score 3 (24.7\%).

\section{DISCUSSION}

This study aims to investigate risk factors for occurrence of caries that are caused by certain health habits, attitudes and behaviour and as such they can be highly preventable with adequate health education activities. Regular and proper oral hygiene, the use of fluoride and regular dental visits are of particular importance for maintaining good oral health.

The research has shown that nearly half of respondents $(45.9 \%)$ know that for a thorough cleaning of teeth besides toothbrush and toothpaste it is necessary to use dental floss while more than a third of students (36.2\%) apply that in practice. In a study conducted in Pancevo, $16.2 \%$ of children (4), and in Albania $21 \%$ of children (13) stated that they regularly use dental floss. The analysis of respondents responses showed that 182 students $(44.2 \%)$ do not use anything else besides toothbrush and toothpaste to maintain oral hygiene which agrees with result of research conducted in a group of teenage boys in Banja Luka (14).

Apart from regular and proper oral hygiene, every prevention programme in dentistry must have for its basis prevention of dental caries and application of fluoride both endogenous and exogenous (15). Data on whether the students are informed about fluoride prophylaxis showed that majority of children $(87.4 \%)$ do not know whether the toothpaste they used for brush- 
ing their teeth contains fluoride, while results of research conducted in Sweden showed that $20 \%$ of respondents aged 15 to 16 years were also not familiar with the fact whether the toothpaste contains fluoride or not (16). The highest percentage of children $(88.6 \%)$ does not use fluoride tablets as their peers in Bosnia and Herzegovina (17). Slightly more than a half of respondents $(52.2 \%)$ do not use mouth rinse with fluoride. Low awareness of positive effects of fluoride among children was observed in Serbia where only $21.33 \%$ respondents were informed about impact of fluoride prophylaxis on dental health (18). Similar results were obtained in a study conducted in Pancevo which showed that $35.4 \%$ of children knew that fluoride in toothpaste helps prevent tooth decay while only $9.1 \%$ of respondents used mouth rinse with fluoride (4).

All respondents stated that they have their own oral hygiene kit which is consistent with research conducted in six municipalities (Tivat, Kotor, Herceg Novi, Budva, Ulcinj and Bar) of coastal region of Montenegro. The results ranged from $76.5 \%$ in Ulcinj to $100 \%$ in Bar (19).

Slightly more than half of respondents brush their teeth twice a day, in the morning and in the evening, while $18.2 \%$ of twelve year olds in Bosnia and Herzegovina (17), 81.8\% of respondents in Pancevo (4), $58 \%$ of respondents in Croatia (6) and $42.5 \%$ of respondents in Albania (13) also do it twice day. The research conducted in the area of Banja Luka showed that $53.37 \%$ of twelve year olds from urban areas brushed their teeth twice a day and $33.76 \%$ after each meal while in rural areas the corresponding percentages were $59.23 \%$ and $17.93 \%$ (14). Our research has showed that the lowest incidence of carries occurs among those respondents who believe that the teeth should be brushed after every meal and the highest incidence occurs in children who think that teeth should be brushed once a day. Also, students with excellent and very good grades believe that the teeth should be brushed after every meal while this attitude is less prevalent in schoolchildren with bad grades in school.

In this study about half of respondent have oral health index score 2 while research conducted in Monte- negro showed that the average values of this index in children of both sex in urban compared to rural areas is $1.084: 1.142(\mathrm{t}=1,517, \mathrm{p}>0,05)(20)$. Of the total number of examined students only one respondent had no deposits as opposed to $6.5 \%$ of respondents from research conducted in Republic of Srpska (21).

DMFT index for study population was 1.87 while caries occurred in $81.6 \%$ of examined children. The value of this index was 3.43 in the research conducted in 2006 in Montenegro while carries occurred in $88.35 \%$ of examined children (20). When the comparison with results from similar epidemiological studies conducted in the neighbouring countries was made the average value of the number of diseased permanent teeth per respondent ranged from $2.89 \pm 0.37$ in Romania (22), 3.4 in Macedonia (23), 3.8 in Albania (13), 4.2 in Bosnia and Herzegovina (24) to 4.8 in Croatia (25).

Significantly lower value of DMFT index were recorded in Italy (1.21), Austria (1.50), Germany (0.72), Norway (1.2), Kenya (0.76 — urban areas, 0.36 - rural areas), Brazil (0.9\%), Zimbabwe (1.29\% — urban area, $0.66 \%$ rural area), and slightly higher in Russia (2.95), Lithuania (3.7), Qatar (4.62) and Saudi Arabia (5.49) (26-36). The study conducted in 2010 in Norway showed that the prevalence of dental caries in children is low (8.78) and that most preschool children had no experience with caries as a disease. This could beattributed to the high level of education of the population and free dental care for children from early years (37).

\section{CONCLUSION}

Taking into account the obtain results it can be concluded that dental health care in this area does not significantly affect the improvement of oral health in children. Therefore, a greater attention should be paid to continuous education programmes and gaining knowledge about oral health and hygiene of the mouth and teeth. Special emphasis should be placed on the development of primary dental care that will be based on preventive and prophylactic methods, promotion of oral health and health education particularly of children and then of their parents.

\title{
SAŽETAK
}

\section{ZNAČAJ PONAŠANJA DECE ZA STANJE ORALNOG ZDRAVLJA}

\author{
Anđelić Ivana, ${ }^{1}$ Matijević Snežana, ${ }^{2}$ Anđelić Jasminka ${ }^{1}$ \\ ${ }^{1}$ University of Montenegro, Faculty of Medicine Podgorica, Montenegro \\ ${ }^{2}$ Primary Heath Care Center Tivat, Montenegro
}

Uvod. Karijes ili zubni kvar je danas bez obzira na dobro poznavanje prirode bolesti i mogućnosti njene efikasne prevencije, još uvek najrasprostranjenije oboljenje naše populacije, koje ne retko ugrožava funkcije 
pojedinih organa pa i celog organizma. Zdravstvena kultura predstavlja sastavni deo opšte kulture, a zdravstveno vaspitanje ima veoma važnu ulogu u očuvanju zdravlja pojedinca. Cilj. Osnovni cilj ovog istraživanja je utvrđivanje uticaja ponašanja na oralno zdravlje dece sedmih i osmih razreda uzrasta od 12 do 14 godina $u$ osnovnoj školi "Drago Milović” u Tivtu. Metod. Istraživanje je rađeno u periodu od kraja januara meseca do aprila meseca 2015. godine u osnovnoj školi "Drago Milović" u Tivtu. Obuhvaćena su sva deca sedmih i osmih razreda koja su tih dana bila u školi. Kao instrument istraživanja korišćen je upitnik posebno kreiran za ovo istraživanje koji se sastojao od 36 pitanja zatvorenog tipa. Kao dodatni instrument istraživanja poslužio je klinički pregled oralnog zdravlja dece. Procena stanja oralnog zdravlja kod dece rađena je uz pomoć stomatološkog ogledalca i sonde pri dnevnoj svetlosti prema preporukama SZO. Parametar korišćen za procenu stanja oralnog zdravlja bio je KEP indeks — broj karijesnih, ekstrahovanih plombiranih zuba. Pored toga, rađena je i procena stanja oralne higijene, za šta je korišćen indeks mekih naslaga prema Green-Vermillion-u kojim se određuje, odsustvo odnosno prisustvo,

\section{REFERENCES}

1. Pezelj-Ribarić S, Antonić R, Brekalo-Pršo I, et al. Oralno zdravlje - uvjet za opće zdravlje. Medicinski fakultet Sveučilišta u Rijeci, Rijeka; 2013.

2. Pejčić A, Peševska S, Grigorov I, Bojović M. Periodontitis as a risk factor for general disorders. Acta Facult Med Naiss. 2006; 23(2): 59-65.

3. Castilho ARF, Mialhe FL, Barbosa TS, Puppin-Rontani RM. Influence of family environment on children's oral health: a systematic review. J Pediatr (Rio J). 2013; 89(2): 116-23.

4. Lalić M, Aleksić E, Gajić M, Malešević Đ. Znanje o oralnom zdravlju i zdravstveno ponašanje roditelja i djece školskog uzrasta. Med Pregl. 2013; LXVI (1-2): 70-80.

5. Beloica D, Vulović M, Carević M, et al. Dečja stomatologija. Stomatološki fakultet Univerziteta u Beogradu, Beograd; 2010.

6. Špalj S, Tudor-Špalj V, Ivanković L, Plančak D. Oral health-related risk behaviours and attitudes among Croatian adolescents multiple logistic regression analysis. Coll Antropol. 2014; 38(1): 261-7.

7. Ljaljević A, Matijević S, Terzić N, Anđelić J, Mugoša B. Značaj održavanja oralne higijene za zdravlje usta i zuba. Vojnosanit pregl. 2012; 69(1): 16-22.

8. Twetman S, Ekstrand K, Qvist V. Dental caries in an ecological perspective. Ugeskr Laeg. 2010; 172(44): 3026-9.

9. Wigen TI, Wang Nj. Parental influences on dental caries development in preschool children. Norsk Epidemiologi. 2012; 22(1): 13-9.

10. Christensen LB, Twetman S, Sundby A. Oral health in children and adolescents with different socio-cultural and socio-economic backgrounds. Acta Odontol Scand. 2010; 68(1): 34-42.

11. Vanagas G, Milašauskiene Ž, Grabauskas V, Mickevičiene A. Associations between parental skills and their attitudes količina i rasprostranjenost dentalnog plaka $\mathrm{i}$ ostalih mekih naslaga na zubima. Rezultati. Najveći broj ispitivanih učenika je naveo da nema znanja u vezi sa delotvornošću zubne paste sa fluorom $(69,4 \%)$. Utvrđeno je da se najmanja učestalost dijagnoze karijesa javlja kod onih učenika koji smatraju da zube treba prati posle svakog obroka, a najveća učestalost ove dijagnoze javlja se kod ispitanika koji smatraju da zube treba prati jednom dnevno. Polovina od ukupnog broja ispitivane dece imaju stav da zube najčešće treba prati posle svakog jela $\mathrm{i}$ to više od polovine odličnih učenika $(55,6 \%)$. U ispitivanoj populaciji KEP indeks je iznosio 1,87, dok je ispitivanjem Green-Vermillionovog indeksa mekih naslaga (oralne higijene) kod najvećeg broja učenika identifikovan indeks drugog stepena naslaga (49,5\%). Zaključak. Sagledavajući dobijene rezultate, može se zaključiti da stomatološka zaštita na ovom području ne utiče značajno na poboljšanje oralnog zdravlja kod dece. Stoga bi veću pažnju trebalo posvetiti kontinuiranim edukativnim programima i sticanju znanja o oralnom zdravlju i higijeni usta i zuba.

Ključne reči: Deca, oralno zdravlje, zdravstveno vaspitanje, KEP indeks, Green-Vermillionov indeks.

toward importance to develop good oral hygiene skills in their children. Medicina (Kaunas). 2009; 45(9): 718-23.

12. Bozorgmehr E, Hajizamani A, Malek MT. Oral health behavior of parents as a predictor of oral health status of their children. ISRN Dent. 2013; 2013: 741783. DOI:10.1155/2013/741783.

13. Hysi D, Droboniku E, Toti C, Xhemnica L, Petrela E. Dental caries experience and oral health behavior among 12-year-olds in the city of Tirana, Albania. Journal of Oral Health and Dental Management. 2010; 9: 229-34.

14. Obradović M, Dolić O. Caries prevalence and risk factors for its development in urban and rural regions. Stomatološki glasnik Srbije. 2008; 55(1): 34-42.

15. Igić M, Apostolović M, Kostadinović Lj, Šurdilović D, Tričković-Janjić $\mathrm{O}$. The application of fluoride in prevention of caries. Acta Stom Naissi. 2008; 24(57): 783-7.

16. Jensen O, Gabre P, Skold UM, Birkhed D. Is the use of fluoride toothpaste optimal? Knowledge, attitudes and behaviour concerning fluoride toothpaste and toothbrushing in different age groups in Sweden. Community Dent Oral Epidemiol. 2012; 40(2): 175-84.

17. Davidović B, Ivanović M, Janković S, Lečić J. Knowledge, attitudes and behavior of children in relation to oral health. Vojnosanit Pregl. 2014; 71(10): 949-56.

18. Igić M, Apostolović M, Kostadinović Lj, Tričković-Janjić O, Šurdilović D. Stepen informisanosti sedmogodišnjaka i roditelja o uticaju ishrane, oralne higijene i profilakse fluorom na zdravlje zuba. Med Pregl. 2009; 62(9-10): 421-6.

19. Matijević S. Povezanost navika u zdravlju i prisustvo oralne patologije kod djece u Crnoj Gori. Acta Stomatologica Naissi. 2009; 25(59): 869-82.

20. Đuričković M, Ivanović M. Stanje oralnog zdravlja kod djece uzrasta od 12 godina u Crnoj Gori. Vojnosanit Pregl 2011; 68 (7): 550-5. 
21. Davidović B, Janković S, Ivanović D, et al. Procjena uticaja promocije oralnog zdravlja u djece istočnog dijela Republike Srpske. Biomedicinska istraživanja. 2011; 2(1): 11-19.

22. Zmarandache DDD, Luca R, Chis AC, Farcasiu C. Carious activity in 12 year-old children from Slatina, Romania. International Journal of Medical Dentistry. 2012; 2 (1): 27-32.

23. Ambrakova V, Ivanova V. Dental caries experience among primary school children in eastern region of the Republic of Macedonia. Oral Health \& Dental Management. OHDM 2014; 13(1): 514-20.

24. Marković N, Arslanagić Muratbegović A, Kobaslija S, Bajrić E, Selimović-Dragas M, Huseinbegović A. Caries prevalence of children and adolescents in Bosnia and Herzegovina. Acta Med Acad. 2013; 42(2): 108-16.

25. Dukić W, Delija B, Lulić Dukić O. Caries prevalence among schoolchildren in Zagreb, Croatia. Croat Med J. 2011; 52(6): 665-71.

26. Napoli C, Trerotoli P, Solinas G, et al. Caries experience among adolescents in southeast Italy. J Dent Sci. 2012; 7(2): 89-93.

27. Cvikl B, Haubenberger-Pralml G, Drabo P, et al. Migration background is associated with caries in Viennese school children, even if parents have recived a higher education. BMC Oral Health. 2014; 14: 51.

28. Pieper K, Lange J, Jablonski-Momeni A, Schulte AG. Caries prevalence in 12-year-old children from Germany: results of the 2009 national survey. Community Dental Health. 2013; 30(3): 138-42

29. Koposova N, Eriksen HM, Widstrom E, Handegard $\mathrm{BH}$, Pastbin M, Koposov R. Caries prevalence and determinants among 12-year-olds in North-West Russia and Northen Norway. Stomatol. 2013; 15(1): 3-11.

30. Gathecha G, Makokha A, Wanzala P, Omolo J, Smith P. Dental caries and oral health practices among 12 year old children in Nairobi West and Mathira West Districts, Kenya. Pan Afr Med J. 2012; 12: 42-9.

31. Piovesan C, Mendes FM, Antunes JL, Ardenghi TM. Inequalities in the distribution of dental caries among 12-year-old Brazilian schoolchildren. Braz Oral Res. 2011; 25(1): 69-75.

32. Mafuvadze BT, Mahachi L, Mafuvadze B. Dental caries and oral health practice among 12 year old school children from low socio-economic status background in Zimbabwe. Pan Afr Med J. 2013; 14:164-70.

33. Gorbatova MA, Grjibovski AM, Gorbatova LN, Honkala E. Dental caries experience among 12-year-old children in Northwest Russia. Community Dent Health. 2012; 29(1): 20-4.

34. Milciuviene $\mathrm{S}$, Bendoraitiene $\mathrm{E}$, Andruskeviciene $\mathrm{V}$, et al. Dental caries prevalence among 12-15-year-olds in Lithuania between 1983-2005. Medicina (Kaunas). 2009; 45: 68-76.

35. Al-Darwish M, El Ansari W, Bener A. Prevalence of dental caries among 12-14 year old children in Qatar. Saudi Dent J. 2014; 26(3): 115-25.

36. Al-Sadhan S. Dental caries prevalence among 12-14 year-old schoolchildren in Riyadh: a 14 year follow-up study of the oral health survey of Saudi Arabia phase I. Saudi Dent J. 2006;18: 2-7.

37. Wigen TI, Wang Nj. Parental influences on dental caries development in preschool children. An overview with emphasis on recent Norwegian research. Norsk Empidemiologi. 2012; 22(1): 13-9.

\section{Correspondence to /Autor za korespondenciju}

Ivana Andjelic

Email: ivaand89@gmail.com

Tel: +38269883801 